\title{
Sistem Pendukung Keputusan Pengangkatan Karyawan Tetap Menggunakan Metode Analytic Hierachy Process
}

\author{
Ahmad Fauzi ${ }^{* 1)}$, Novita Indriyani' ${ }^{2}$, Andika Bayu Hasta Yanto ${ }^{3)}$ \\ ${ }^{1)}$ Program Studi Sistem Informasi Akuntansi, Universitas Bina Sarana Informatika \\ ${ }^{2)}$ Program Studi Sistem Informasi Akuntansi, Universitas Bina Sarana Informatika Kampus Kota Bogor \\ ${ }^{3}$ Program Studi Teknik Industri, Universitas Universitas Bina Sarana Informatika \\ *)Correspondence author: ahmad.afz@bsi.ac.id, DKI Jakarta, Indonesia
}

\begin{abstract}
Abstrak
Karyawan adalah motor penggerak berjalannya proses bisnis dalam sebuah perusahaan. Perusahaan yang memiliki karyawan dengan kualitas dan kompetensi yang baik akan membuat semua proses pekerjaan dapat dikelola dengan mudah. Salah satu bentuk upaya peningkatan kualitas dan kompetensi adalah pengangkatan karyawan menjadi karyawan tetap. Pengangkatan karyawan tetap merupakan agenda yang dilaksanakan oleh perusahaan dimana usaha pengembangan karier bagi seorang pegawai kontrak yang telah dijalaninya selama masa perjanjian kontrak. Manfaat dari proses perekrutan dan seleksi adalah untuk mendapatkan orang yang tepat untuk sumber daya manusia yang baru. Perekrutan dan seleksi merupakan proses yang lama, rumit, dan banyak peluang untuk membuat keputusan yang salah. Ini berarti terdapat pula kemungkinan besar bahwa karyawan yang akan diterima tidak mencapai standar yang diinginkan. Ini juga berarti kemungkinan sangat besar untuk tidak memperoleh kandidat terbaik. Terutama jika pengangkatan karyawan merupakan sesuatu yang penting untuk keberhasilan atau kegagalan suatu perusahaan. Sistem pendukung keputusan dapat digunakan sebagai alat untuk mengevaluasi atas kinerja karyawan yaitu dengan menggunakan salah satu metode dalam sistem pendukung keputusan. Metode yang digunakan yaitu Analythic Hierarchy Process (AHP).
\end{abstract}

Kata Kunci: Sistem Pendukung Keputusan, Analythic Hierarchy Process, Perekrutan Karyawan

\begin{abstract}
Employees are the driving force behind the running of business processes in a company. Companies that have employees with good quality and competence will make all work processes can be managed easily. One form of efforts to improve quality and competence is the appointment of employees as permanent employees. The appointment of permanent employees is an agenda carried out by the company where a career development effort for a contract employee has been undertaken during the contract agreement period. The benefit of the recruitment and selection process is to get the right people for new human resources. Recruitment and selection is a long, complicated process, and many opportunities for making wrong decisions. This means that there is also a high likelihood that employees will not be accepted to the desired standard. This also means that there is a high probability of not getting the best candidate. Especially if the appointment of employees is something important for the success or failure of a company. Decision support systems can be used as a tool for evaluating employee performance by using one of the methods in a decision support system. The method used is the Analysis Hierarchy Process (AHP).
\end{abstract}

Keywords: Decision Support System, Analytic Hierarchy Process, Employee Recruitment

\section{PENDAHULUAN}

Karyawan adalah motor penggerak berjalannya proses bisnis dalam sebuah perusahaan. Perusahaan yang memiliki karyawan dengan kualitas dan kompetensi yang baik akan membuat semua proses pekerjaan dapat dikelola dengan mudah. Salah satu bentuk upaya peningkatan kualitas dan kompetensi adalah pengangkatan karyawan menjadi karyawan 
tetap. Pengangkatan karyawan tetap merupakan agenda yang dilaksanakan oleh perusahaan sebagai usaha pengembangan karier bagi seorang pegawai kontrak yang telah menjalani masa perjanjian kontrak. Manfaat dari proses perekrutan dan seleksi adalah untuk mendapatkan orang yang tepat untuk sumber daya manusia yang baru. Perekrutan dan seleksi merupakan proses yang lama, rumit, dan banyak peluang untuk membuat keputusan yang salah. Ini berarti terdapat pula kemungkinan besar bahwa karyawan yang akan diterima tidak mencapai standar yang diinginkan. Ini juga berarti kemungkinan sangat besar untuk tidak memperoleh kandidat terbaik. Terutama jika pengangkatan karyawan merupakan sesuatu yang penting untuk keberhasilan atau kegagalan suatu perusahaan. Menurut Turban et al (2005:321) menjelaskan bahwa "Decision Support System (DSS) adala sistem informasi berbasis komputer yang menggabungkan model dan data untuk memberikan dukungan bagi para pembuat keputusan dalam memecahkan masalah semi terstruktur atau saling tergantung yang melibatkan pengguna secara ekstensif”.

Sistem Pendukung Keputusan (SPK) sebagai sistem yang memiliki lima karakteristik utama, yaitu:

1. Sistem yang berbasis komputer.

2. Dipergunakan untuk membantu para pengambil keputusan

3. Untuk memecahkan masalah-masalah rumit yang mustahil dilakukan dengan kalkulasi manual

4. Melalui cara simulasi yang interaktif

5. Data dan model analisis sebagai komponen utama.

\section{METODE}

Untuk menghasilkan suatu keputusan yang tepat dan transparan, diperlukan suatu metode yang mampu memberikan solusi dalam menentukan karyawan tetap sehingga perusahaan dan karyawan tidak merasa dirugikan. Sistem Pendukung Keputusan (SPK) merupakan sistem yang memberikan dukungan solusi dari masalah yang semi terstruktur dan terstruktur, SPK mendukung berbagai level, untuk individu dan juga kelompok. Ada banyak metode yang bisa digunakan dalam membantu menunjang keputusan. Fuzzy Multi Attribute Decision Making merupakan salah satu metode penunjang pengambilan keputusan yang cukup sederhana dan dapat menjadi salah satu alternatif dalam mengambil keputusan jika alternative atau attribute yang digunakan cukup banyak dan bernilai data kuantitatif. Fuzzy Multi Attribute Decision Making sendiri memiliki beberapa metode didalamnya yang dapat membantu memberikan alternatif terbaik diantaranya: ELECTRE, Analytic Hierarchy Prosess (AHP), Simple Additive Weighting (SAW), Technique for 
Order Preference by Similarity to Ideal Solution (TOPSIS) dan Weighted Product (WP). Untuk menyelesaikan permasalahan diatas akan menggunakan metode AHP (Analytic Hierarchy Process).

Menurut (Saaty, 1993) metode AHP membantu memecahkan persoalan yang kompleks dengan menstrukturkan suatu hirarki kriteria, pihak yang berkepentingan, hasil dan dengan menarik berbagai pertimbangan guna mengembangkan bobot atau prioritas. Metode ini juga menggabungkan kekuatan dari perasaan dan logika yang bersangkutan pada berbagai persoalan, lalu mensintesis berbagai pertimbangan yang beragam menjadi hasil yang cocok dengan perkiraan kita secara intuitif sebagaimana yang dipresentasikan pada pertimbangan yang telah dibuat. Pada perkembangannya, AHP dapat memecahkan masalah yang kompleks atau tidak berkerangka dengan aspek atau kriteria yang cukup banyak. Kompleksitas ini disebabkan oleh struktur masalah yang belum jelas, ketidakpastian persepsi pengambilan keputusan, serta ketidakpastian tersedianya atau bahkan tidak ada sama sekali data statistik yang akurat. Adakalanya timbul masalah keputusan yang dirasakan dan diamati perlu diambil secepatnya, tetapi variasinya rumit sehingga datanya tidak mungkin dapat dicatat secara numerik, hanya secara kualitatif saja yang dapat diukur, yaitu berdasarkan persepsi pengalaman dan intuisi, Namun, tidak menutup kemungkinan, bahwa model model lainnya ikut dipertimbangkan pada saat proses pengambilan keputusan dengan pendekatan AHP, khususnya dalam memahami para pengambil keputusan individual pada saat proses penerapan pendekatan ini.

Ada beberapa langkah yang harus dipahami didalam menyelesaikan masalah dengan menggunakan metode AHP, yaitu (Kusrini, 2007) :

1. Membuat hierarki

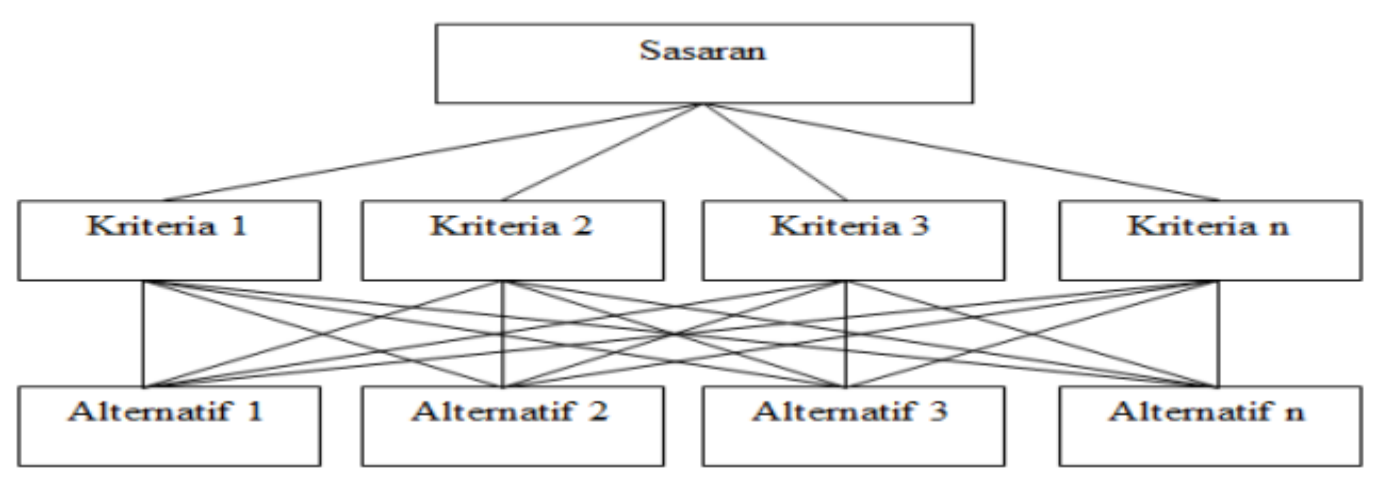

Gambar 1. Hierarki AHP 
Sistem yang kompleks bisa dipahami dengan memecahnya menjadi elemen-elemen pendukung, menyusun elemen secara hierarki, dan menggabungkannya atau mensintesisnya.

2. Penilaian kriteria dan alternatif

Pemberian bobot kriteria dan alternatif dilakukan dengan membuat matriks perbandingan berpasangan. Menurut Saaty dalam Kusrini (2007), untuk berbagi persoalan, skala 1 sampai 9 adalah skala terbaik untuk mengekspresikan pendapat. Nilai dan definisi pendapat kualitatif dari skala perbandingan Saaty bisa diukur menggunakan tabel analisis seperti ditunjukkan pada Tabel 1 berikut ini :

Tabel 1. Skala Penilaian Perbandingan Berpasangan

\begin{tabular}{cl}
\hline $\begin{array}{c}\text { Intensitas } \\
\text { Kepentingan }\end{array}$ & \multicolumn{1}{c}{ Keterangan } \\
\hline 1 & Kedua elemen sama pentingnya (Equal Importance) \\
\hline 3 & $\begin{array}{l}\text { Elemen yang satu se dikit lebih penting daripada elemen } \\
\text { yang lainnya (Slightly more Importance) }\end{array}$ \\
\hline 5 & $\begin{array}{l}\text { Elemen yang satulebih penting daripada yang lainnya } \\
\text { (Meterially more Importance) }\end{array}$ \\
\hline 7 & $\begin{array}{l}\text { Satu Elemen jelas lebih mutlak penting daripada elemen } \\
\text { lainnya (Significantly more Importance) }\end{array}$ \\
\hline 9 & $\begin{array}{l}\text { Satu Elemen mutlak penting daripada elemen la innya } \\
\text { (Compromise Values) }\end{array}$ \\
\hline $2,4,6,8$ & $\begin{array}{l}\text { Nilai-nilai antara dua nilai pertimbangan-pertimbangan } \\
\text { yang berdekatan (Compromise Values) }\end{array}$ \\
\hline
\end{tabular}

Sumber: Kusrini(2007)

\section{Menentukan Prioritas}

Untuk setiap kriteria dan alternatif, perlu dilakukan perbandingan berpasangan (pairwise comparisons). Nilai-nilai perbandingan relatif dari seluruh alternatif kriteria bisa disesuaikan dengan judgement yang telah ditentukan untuk menghasilkan bobot dan prioritas. Bobot dan prioritas dihitung dengan memanipulasi matriks atau melalui penyelesaian persamaan matematika.

\section{Konsistensi Logis}


Konsistensi memiliki dua makna. Pertama objek objek yang serupa bisa dikelompokkan sesuai dengan keseragaman dan relevansi. Kedua, menyangkut tingkat hubungan antar objek yang didasarkan pada kriteria tertentu.

Perhitungan indeks konsistensi (CI), pengukuran ini dimaksudkan untuk mengetahui konsistensi jawaban yang akan berpengaruh pada keakuratan dari hasil yang dihasilkan. Adapun rumus menghitung (CI) adalah sebagai berikut :

$$
C I=\frac{\lambda_{\max }-n}{n-1}
$$

Untuk mengetahui apakah nilai besaran CI yang dihasilkan cukup baik atau tidak perlu kita ketahui nilai CR (Ratio)nya. CR yang di anggap baik bila $\mathrm{CR}<0,1$. Adapun rumus untuk menghitung CR adalah sebagai berikut :

$$
C R=\frac{C I}{R I}
$$

Penghitungan konsistensi logis dilakukan dengan mengikuti langkah-langkah sebagai berikut:

a. Mengalikan matriks dengan prioritas bersesuaian

b. Menjumlahkan hasil perkalian perbaris c. Hasil penjumlahan tiap baris dibagi prioritas bersangkutan dan hasilnya dijumlahkan

c. Hasil c dibagi jumah elemen akan didapat $\lambda$ maks

d. Indeks Konsistensi= CI / RI, dimana RI adalah indeks random konsistensi. Jika rasio konsistensi $\leq 0.1$, hasil perhitungan data dapat dibenarkan.

Nilai RI didasarkan pada penelitian yang dilakukan oleh Saaty (1993), yang ditunjukan pada tabel 2.

Tabel 2. Nilai Indeks Random

\begin{tabular}{|c|c|c|c|c|c|c|c|c|c|c|}
\hline $\begin{array}{c}\text { Orde } \\
\text { Matriks }\end{array}$ & 1 & 2 & 3 & 4 & 5 & 6 & 7 & 8 & 9 & 10 \\
\hline $\mathrm{RI}$ & 0,00 & 0,00 & 0,58 & 0,90 & 1,12 & 1,24 & 1,32 & 1,41 & 1,45 & 1,49 \\
\hline
\end{tabular}

\section{HASIL DAN PEMBAHASAN}


Analisa pendapat gabungan para responden yang telah di proses menghasilkan landasan kriteria sebagai berikut:

Priorities with respect to:
Pengangkatan Kry Tetap
Disiplin
Kinerja
Loyalitas
Masa Kerja
Inconsistency = 0.09
with 0 missing judgments.

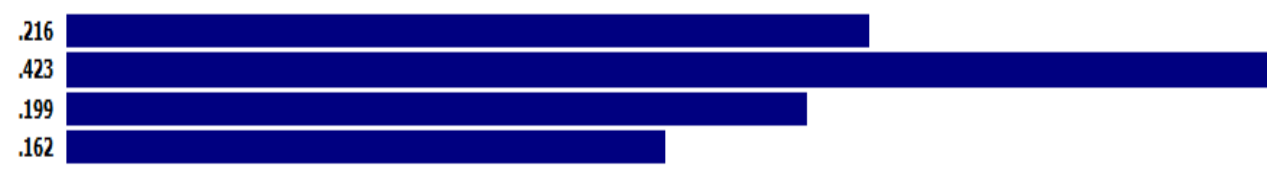

Gambar 2. Bobot Landasan Nilai Kriteria

Landasan kriteria menghasilkan beberapa alternative pemilihan. Pembagiannya adalah sebagai berikut:

\section{Disiplin}

Priorities with respect to:
Pengangkatan Kry Tetap
>Disiplin
Budi Suryana
Dini Ayuningtyas
Citra Umami
Rahmat Aryadi
Inconsistency $=0.12$
with 0 missing judgments.

Gambar 3. Bobot Nilai Landasan Alternative Berdasarkan Kriteria Disiplin

\section{Kinerja}

Priorities with respect to: Pengangkatan Kry Tetap $>$ Kinerja
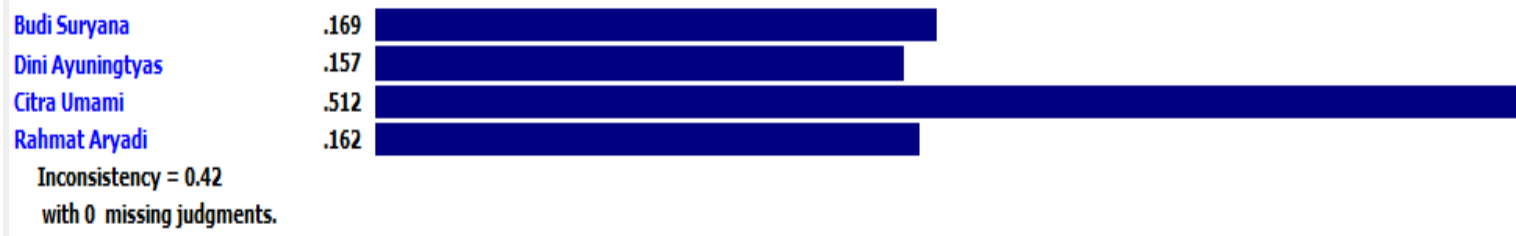

Gambar 4. Bobot Nilai Landasan Alternative Berdasarkan Kriteria Kinerja

3. Loyalitas 


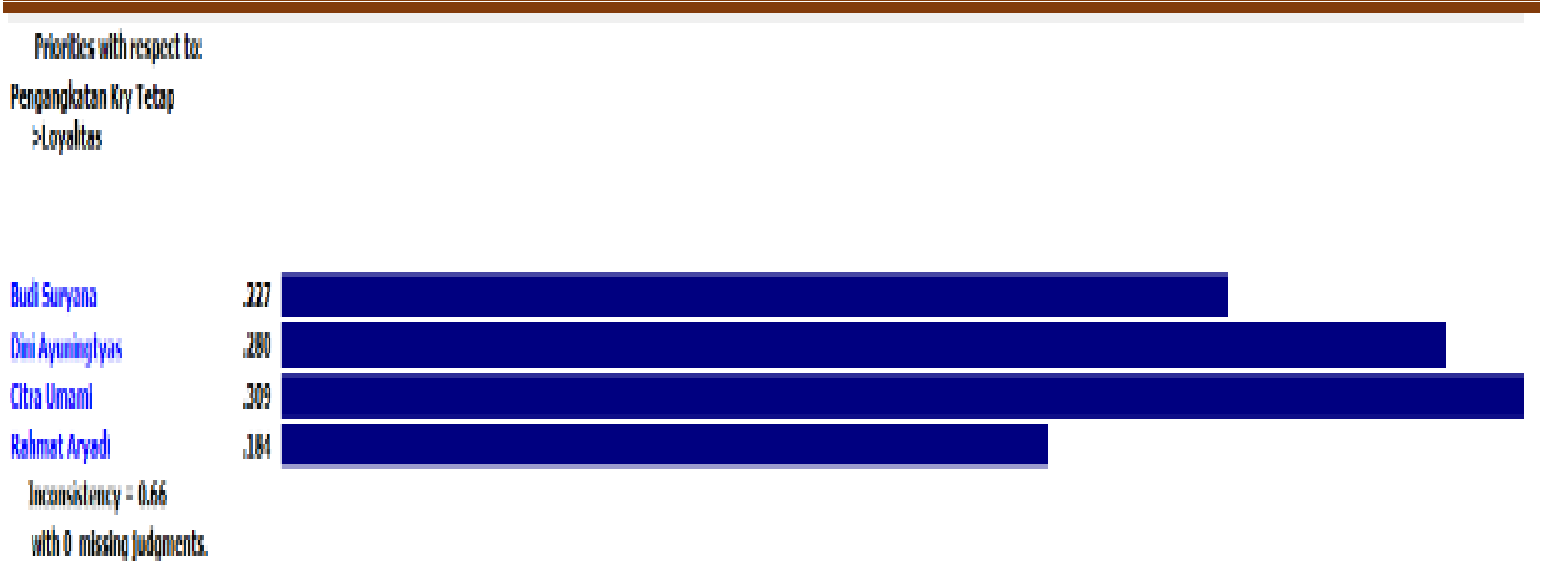

Gambar 5. Bobot Nilai Landasan Alternative Berdasarkan Kriteria Loyalitas

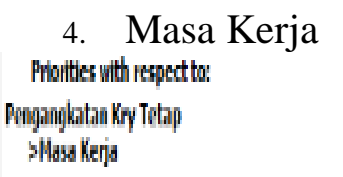

\begin{tabular}{|c|}
\hline Budi 5uryana \\
\hline DinilApuningtyas \\
\hline Clth Umaml \\
\hline Batinat Andidi \\
\hline
\end{tabular}

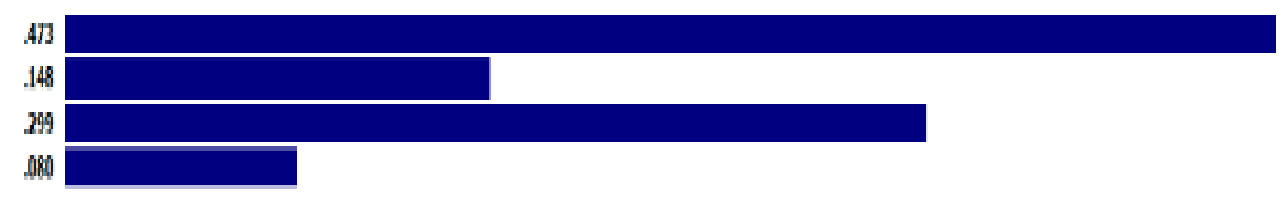

Gambar 6. Bobot Nilai Landasan Alternative Berdasarkan Kriteria Masa Kerja

Setelah melalui hasil perhitungan maka didapatkan hasil:

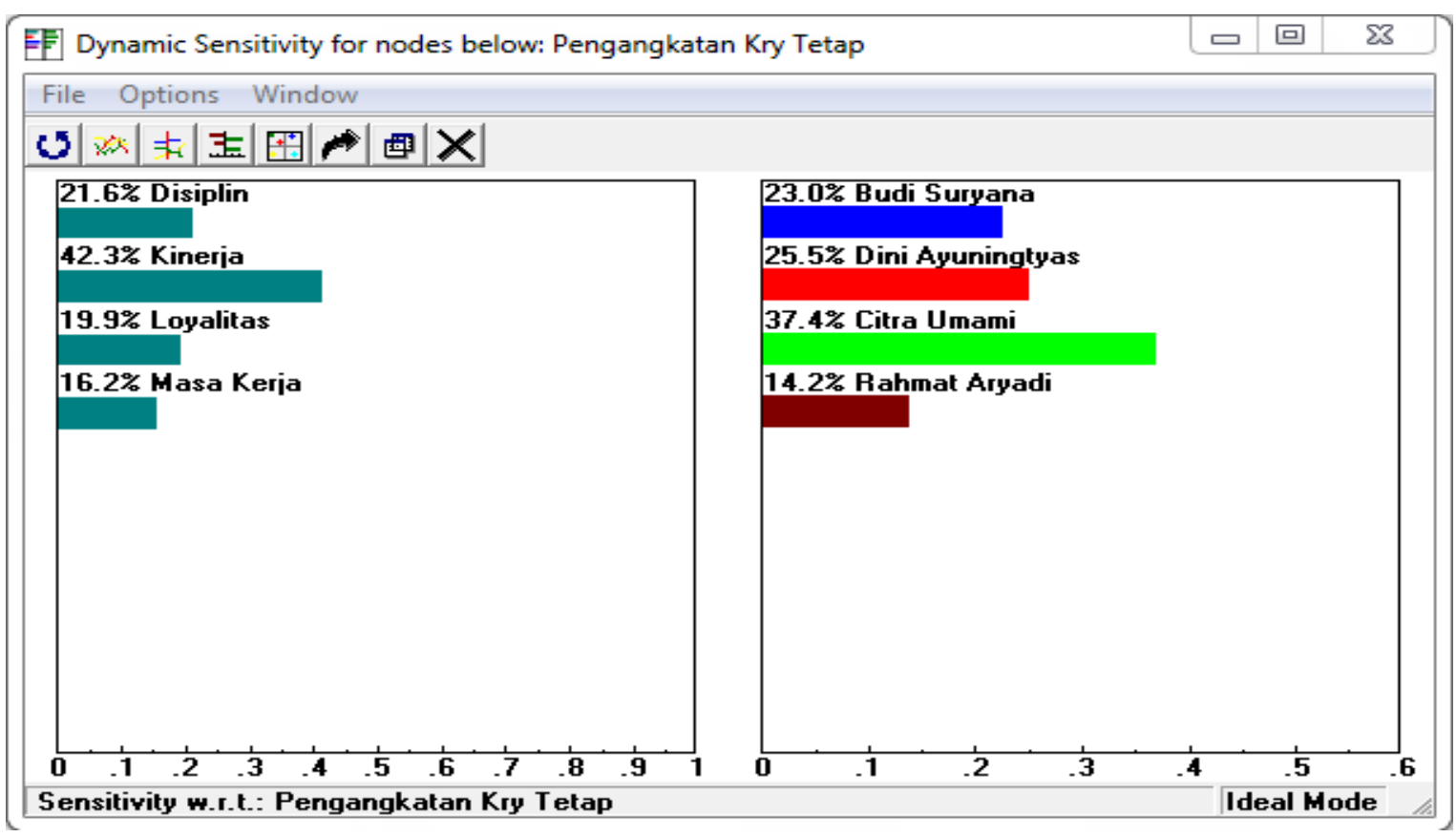

Gambar 7. Perbandingan antara kriteria utama dan alternatif

\section{KESIMPULAN DAN REKOMENDASI}


Dari pembahasan diatas dapat disimpulkan, Sistem pendukung keputusan dapat digunakan sebagai alat untuk mengevaluasi kinerja karyawan yaitu dengan menggunakan salah satu metode dalam sistem pendukung keputusan. Metode yang digunakan yaitu Analythic Hierarchy Process (AHP). Kriteria utama dalam pengangkatan karyawan tetap adalah Kinerja dengan bobot $42,3 \%$. Alternative utama dalam pengangkatan karyawan tetap pada contoh kasus diatas adalah Citra Umami dengan bobot 37,4\%.

Direkomendasikan untuk menambahkan jumlah kriteria dan juga menambahkan sub kriteria dalam pengangkatan karyawan tetap agar semakin ketat dalam melakukan penyeleksian.

\section{REFERENSI}

Amborowati, A. (2008). Sistem Pendukung Keputusan Pemilihan Karyawan Berprestasi Berdasarkan Kinerja (Studi Kasus Pada STMIK AMIKOM Yogyakarta). E-Jurnal.

Kusrini. (2007). Konsep Dan Aplikasi Sistem Pendukung. Yogyakarta: Andi.

Nofriansyah, D. (2004). Konsep Data Mining Vs Sistem. Yogyakarta: Deepublish.

Saaty, T. (1993). Decision Making for Leader: The Analytical Hierarchy Process for Decision in Complex World. Pittsburgh: Prentice Hall Coy Ltd.

Suryadi DEA, K., \& Ramdhani, A. (2002). Sistem Pendukung Keputusan. Bandung: RosdaKarya.

Turban, E., E.Aronson, J., \& Liang, T.-P. (2005). Decision Support System and Intelligent System (Sistem Pendukung Keputusan dan Sistem Cerdas) Edisi 7. Yogyakarta: Andi. 